\title{
Detecção de bactérias associadas a gemas de pereiras europeias no Rio Grande do Sul
}

\author{
Cátia C. Rommel ${ }^{1}$, Rosa M. Valdebenito-Sanhueza ${ }^{2}$ \& Valmir Duarte ${ }^{1}$ \\ ${ }^{1}$ Departamento de Fitossanidade, Universidade Federal do Rio Grande do Sul, 91.540-000 Porto Alegre, RS, Brasil; ${ }^{2}$ Proterra \\ Engenharia Agronômica, 95200-000 Vacaria, RS, Brasil
}

Autor para correspondência: Cátia C. Rommel, e-mail: catiarommel@hotmail.com

\begin{abstract}
RESUMO
A morte de flores em pomares de pereiras europeias (Pyrus communis L.) foi observada em Vacaria, RS. Dois isolados bacterianos, oriundos de flores sintomáticas, reproduziram tais sintomas em flores de ramos destacados e foram identificados como Pseudomonas sp. Devido à ausência de registro da etiologia dessa doença no Brasil, ao registro de P. syringae pv. syrigae e Erwinia amylovora associadas a sintomas similares em outros países e à possível presença deste tipo de bactérias em gemas, um método para detecção dessas três bactérias foi desenvolvido. O método envolveu maceração das gemas com nitrogênio líquido, adição de PBS e PVP $2 \%$, transferência do suco para cartão FTA (Whatman); tratamento de círculos do cartão, com etanol 70\%, reagente FTA e tampão TE, eluição do DNA seguida de PCR com oligonucleotídeos iniciadores específicos para cada uma das bactérias. O método foi, então, utilizado para monitorar tais bactérias em gemas colhidas bimensalmente durante 2008. E. amylovora não foi detectada. A frequência média de $P$. syringae pv. syringae e Pseudomonas sp. foi de 0,7 e 16,3\%, respectivamente; a última atingindo pico de $30 \%$ em outubro. A espécie do agente causal não foi elucidada, mas foi demonstrada a associação com o gênero Pseudomonas, o que já fornece subsídios para o desenvolvimento de métodos de controle da doença.
\end{abstract}

Palavras-chave: Pseudomonas sp., Pseudomonas syringae pv. syringae, Erwinia amylovora, Pyrus communis, PCR.

\begin{abstract}
Detection of bacteria associated with European pear buds in Rio Grande do Sul State, Brazil

The death of flowers in European pear (Pyrus communis L.) orchards was observed in Vacaria, State of Rio Grande do Sul, Brazil. Two bacterial isolates, obtained from symptomatic flowers, reproduced these symptoms on flowers of detached branches and were identified as Pseudomonas sp. Considering the lack of reports of this disease in Brazil, the record of P. syringae pv. syrigae and Erwinia amylovora associated with similar symptoms in other countries and the possible presence of these bacteria in buds, a method to detect the three bacteria was developed. The method comprised: bud maceration with liquid nitrogen, addition of PBS and 2\% PVP, transfer of juice to FTA cards (Whatman), treatment of card circles with 70\% ethanol, TE buffer and FTA reagent, elution of DNA followed by PCR with specific primers for each bacterium. The method was further used to monitor these bacteria in buds collected bimonthly during 2008 . E. amylovora was not detected. The average frequency of P. syringae pv. syringae and Pseudomonas sp. was 0.7 and $16.3 \%$, respectively, the latter showing a frequency peak of $30 \%$ in October. The species of the causal agent was not made clear, but the association with the genus Pseudomonas was demonstrated, which already provides a basis for the development of methods for disease control.
\end{abstract}

Key words: Pseudomonas sp., Pseudomonas syringae pv. syringae, Erwinia amylovora, Pyrus communis, PCR.

\section{INTRODUÇÃO}

Dentre as frutas de clima temperado, a pera é a terceira mais consumida no Brasil, sendo superada apenas pela maçã e pêssego (Nakasu \& Leite, 1990). Em 2005 foram consumidas no país 72 mil toneladas de peras, entretanto, a produção nacional não ultrapassou $20 \mathrm{mil} \mathrm{t} \mathrm{em} 2.303$ ha de área plantada (FAO, 2007). O pouco desenvolvimento de pereiras no Brasil é atribuído à baixa produtividade das plantas, principalmente das cultivares europeias (Pyrus communis L.) (Camelatto et al., 1997).

Os fatores limitantes para a expansão da cultura no Brasil são: a falta de cultivares produtoras de frutas de boa qualidade, adaptadas às condições climáticas, indefinição de porta-enxertos e, principalmente, o abortamento de gemas florais que, em alguns anos e dependendo da cultivar, atinge de 30 a 100\% (Nakasu \& Leite, 1992). Recentemente, observou-se a morte de flores em pomares comerciais de pereiras europeias 'Packham's Triumph', 'Williams' Bon Chretien' e "Abate Fetel' em Vacaria, RS. Os sintomas observados consistem em uma lesão circular e escura sobre o cálice que, em alguns poucos casos, evolui para total necrose do receptáculo floral e morte da flor. Cancros em ramos e crestamento de folhas e ramos não têm sido observados.

O crestamento bacteriano de pereiras europeias, ainda não descrito no Brasil, é considerado uma das principais patologias da pereira (Mansvelt \& Hatting, 1990). Os sintomas dessa doença, associada a Pseudomonas syringae pv. syringae, descritos por Panagopolous \& Crosse 
(1964), assemelham-se, em alguns aspectos, aos observados nas flores de pereiras europeias em pomares de Vacaria. Segundo estes autores, as sépalas e o receptáculo floral são os órgãos florais mais afetados pelo crestamento bacteriano, onde lesões circulares, de coloração negra e bordas mais ou menos irregulares, aparecem. No pedicelo, a infecção inicial é na forma de estrias negras ao longo do eixo. Com o progresso da doença, todos tecidos da flor são afetados, ocasionando crestamento e morte rápida. Necrose no cálice, manchas necróticas em frutos e folhas e cancros nos ramos podem ocorrer.

A queima bacteriana associada a Erwinia amylovora apresenta um quadro sintomatológico bastante distinto, no entanto, pode ser confundida, no início, com o crestamento bacteriano em pereiras europeias devido à necrose do receptáculo floral e o crestamento de flores. (Aldwinckle \& Beer, 1979; Panagopoulus \& Crosse, 1964; Qiu et al., 2008). E. amylovora é considerada praga quarentenária (Ministério da Agricultura, 2008) e, portanto, merece especial atenção ante a possibilidade de ser confundida com outra bactéria já presente no país.

A semelhança de sintomas entre o crestamento bacteriano associado a $P$. syringae pv. syringae e a morte de flores nos pomares de pereira europeia de Vacaria não é evidência suficiente para se concluir sobre a etiologia da doença, pois não há registros no país da associação deste patógeno com pereiras. Além disso, existe a possibilidade de confusão de alguns sintomas com os associados a uma praga quarentenária. Portanto, se faz necessário um completo estudo etiológico e epidemiológico da doença observada. Como parte desse estudo (Rommel, 2009), verificou-se por meio de testes bioquímicos, fisiológicos, PCR e sequenciamento que os isolados Pack9 e Pack10, obtidos a partir de flores com sintomas e que reproduziram os mesmos sintomas em flores de ramos destacados podendo ser reisolados, foram identificados como pertencentes ao gênero Pseudomonas, mas não puderam ser conclusivamente enquadrados nas espécies patogênicas descritas por Schaad et al. (2001).

Em função do curto período de floração, duas a três semanas na primavera, existem dificuldades práticas para estudos mais aprofundados sobre a morte de flores de pereira europeia. Entretanto, existe o indicativo de que o inóculo do crestamento na flor já pode estar presente na gema dormente, pois os sintomas de crestamento bacteriano em flores são semelhantes aos observados em gemas florais dormentes, em caso de alta severidade de crestamento associado a P. syringae pv. syringae (Montesinos \& Vilardell, 2001). Da mesma forma, E. amylovora também é encontrada em gemas de pereiras (Miller \& Schroth, 1972).

A fim de contribuir com a elucidação da etiologia e epidemiologia da morte de flores de pereiras europeias observada em Vacaria, objetivou-se com este trabalho i. desenvolver um método rápido, baseado em PCR, de deteç̧ão de Pseudomonas spp., P. syringae pv. syringae e E. amylovora em gemas de pereiras europeias, ii. verificar a associação entre patógeno e hospedeiro por meio da detecção destas bactérias em gemas coletadas em um pomar de pereiras europeias em que se observou a morte de flores e iii. observar a flutuação populacional destas bactérias ao longo do ano.

\section{MATERIAL E MÉTODOS}

\section{Padronização do método de extração de DNA e deteç̧ão}

Cinco gemas de pereiras foram maceradas dentro de microtubos contendo $500 \mu \mathrm{L}$ de suspensão em PBS (NaCl, 8; $\mathrm{KCl}, 0,2 ; \mathrm{Na}_{2} \mathrm{HPO}_{4}, 1,44 ; \mathrm{KH}_{2} \mathrm{PO}_{4}, 0,24 \mathrm{~g} \mathrm{~L}^{-1}$; água destilada para completar o volume) de células bacterianas $\left(10^{8}\right.$ UFC. $\mathrm{mL}^{-1}$ ) do isolado Pack9 e Pseudomonas syringae pv. syringae (IBSBF 281, Instituto Biológico, 2008) (Pss281). Os macerados foram submetidos aos seguintes protocolos de extração de DNA: (1) fervura a $96^{\circ} \mathrm{C}$ por $10 \mathrm{~min}$; (2) Lise de Edwards; (3) FTA ${ }^{\circledR}$ Plant Card Whatman (FTA) (Rajendram et al, 2006); (4) FTA com pré-lavagem em álcool 70\%; (5) FTA e adição de 2\% de Polivinilpirrolidona (PVP); (6) FTA com pré-lavagem em álcool $70 \%$ e adição de $2 \%$ de PVP; (7) Lise de Edwards, FTA com pré-lavagem em álcool 70\% e adição de $2 \%$ de PVP. Os diferentes métodos também foram usados para extração do DNA dos isolados a partir de cultura pura e, além do método de extração, testou-se a maceração das gemas com palito de madeira e micropistilo descartável.

Para extração por cartões FTA transferiram-se $100 \mu \mathrm{L}$ do macerado para superfície do cartão e deixouse secar em temperatura ambiente $\left(25^{\circ} \mathrm{C}\right)$ por, no mínimo, três horas. Discos de $3 \mathrm{~mm}$ de diâmetro foram retirados dos cartões utilizando um cortador (Harris) e transferidos para microtubos de $200 \mu \mathrm{L}$. Entre cada procedimento, desinfestou-se o cortador em álcool $70 \%$. Os discos de papel foram lavados duas vezes, durante $5 \mathrm{~min}$, com 200 $\mu \mathrm{L}$ do reagente FTA (FTA PurificationF Reagent), seguido por duas lavagens com $200 \mu \mathrm{L}$ de tampão TE-1 $(10 \mathrm{mM}$ Tris$\mathrm{HCl}$; 0,1 mM, EDTA, pH 8,0) por 5 min. Posteriormente, as amostras foram secas durante $20 \mathrm{~min}$ a $56^{\circ} \mathrm{C}$, antes da eluição.

O DNA retido no cartão FTA foi eluído adicionandose $35 \mu \mathrm{L}$ de solução alcalina $(0,1 \mathrm{~N} \mathrm{NaOH} ; 0,3 \mathrm{M}$ EDTA, $\mathrm{pH} 13,0)$ aos discos previamente lavados como descrito anteriormente. A solução alcalina foi mantida em contato com o disco do cartão à temperatura ambiente por $5 \mathrm{~min}$. Posteriormente, foram adicionados $65 \mu \mathrm{L}$ de tampão Tris saturado com $\mathrm{Cl}(0,1 \mathrm{M}, \mathrm{pH} 7,0)$, o material foi agitado em vortex durante $5 \mathrm{~s}$, deixado à temperatura ambiente por 10 min e agitado em vortex por $10 \mathrm{~s}$. Os discos de $3 \mathrm{~mm}$ foram pressionados nos seus respectivos tubos e descartados. Para a PCR, $10 \mu \mathrm{L}$ da eluição foram adicionados à solução.

O método que inclui a etapa de pré-lavagem em álcool $70 \%$ do cartão FTA seguiu o mesmo protocolo, entretanto, antes da lavagem com reagente FTA, lavaramse os discos de papel duas vezes, durante $5 \mathrm{~min}$, com 200 
$\mu \mathrm{L}$ de álcool 70\%. Quando exigida pelo método, a adição de PVP $2 \%(\mathrm{~m} / \mathrm{v})$ foi realizada no momento de preparação da suspensão de células bacterianas. O método de extração de DNA através da lise de Edwards diferencia-se pela substituição de PBS (400 $\mu \mathrm{L})$ por tampão de Edwards (200 $\mathrm{mM}$ Tris $\mathrm{HCl} \mathrm{pH}$ 7,5, $250 \mathrm{mM} \mathrm{NaCl}, 25 \mathrm{mM}$ EDTA, 0,5\% SDS) no momento da preparação da suspensão de células bacterianas (Edwards et al., 1991; Kerkoud et al., 2002).

O DNA extraído com os diferentes protocolos foi submetido à PCR em termociclador PTC-100TM (MJ Research, Inc.) com oligos A1 e B6 (Manceau \& Horvais, 1997), universais para várias espécies de Pseudomonas e patovares de $P$. syringae, gerando um fragmento de amplificação de $1050 \mathrm{pb}$. A PCR foi executada com um volume final $20 \mu \mathrm{L}$, composta por $0,5 \mu \mathrm{M}$ de oligos; $1 \mathrm{x}$ tampão de reação (20 mM Tris pH 8,4; $50 \mathrm{mM} \mathrm{KCl}) ; 3,0$ $\mathrm{mM} \mathrm{MgCl} ; 20,2 \mathrm{mM}$ dNTP (Invitrogen); 0,25 U Taq DNA polimerase (Invitrogen); $2 \mu \mathrm{L}$ de DNA; $2 \%$ de PVP e com as seguintes condições: desnaturação inicial de $94{ }^{\circ} \mathrm{C}$ por 5 min, seguido por 30 ciclos de $94^{\circ} \mathrm{C}$ por $30 \mathrm{~s}, 55^{\circ} \mathrm{C}$ por 15 s, $72^{\circ} \mathrm{C}$ por 1 min e uma extensão final de $72^{\circ} \mathrm{C}$ durante 5 min. No método de extração de DNA por fervura, $2 \mu \mathrm{L}$ da suspensão fervida foram usados na PCR. Água Milli-Q foi utilizada como controle negativo.

Os produtos da reação foram visualizados em gel de agarose (Invitrogen) $0,8 \%(\mathrm{~m} / \mathrm{v})$, corado com brometo de etídeo $\left(0,5 \mu \mathrm{g} \cdot \mathrm{mL}^{-1}\right)$ e submetido à eletroforese a $50 \mathrm{~V}$ durante $2 \mathrm{~h}$ e $30 \mathrm{~min}$. O marcador de peso molecular $1 \mathrm{~kb}$ Plus DNA Ladder (Invitrogen) foi usado como referência. Os géis foram expostos a luz ultravioleta e documentados através de câmera fotográfica (Sony Cyber-Shot).

\section{Desenho de oligonucleotídeos iniciadores e especificidade in silico}

Sequências relacionadas a características específicas de $P$. syringae pv. syringae e E. amylovora foram selecionadas a partir do banco de genes ENTREZ disponível no National Center for Biotechnology Information
(NCBI, 2008). As sequências foram editadas para o modo FASTA e submetidas à Plataforma BLAST para análise de similaridade das sequências com outras sequências genômicas depositadas no GenBank. Posteriormente, as sequências foram utilizadas como molde para o desenho dos oligos específicos através do programa Primer 3 (2008). Os oligos também foram submetidos à plataforma BLAST para verificar a especificidade in silico. A síntese dos oligos foi realizada pela Integrated DNA Technologies.

A sequência escolhida para o desenho dos oligos específicos para detecção de $P$. syringae pv. syringae foi a do gene $\operatorname{syr} B 1$, cujo produto está envolvido na síntese da siringomicina (número de acesso GenBank U25130.2). Os oligos desenhados foram SyrB1 (5' - CGT ACA TGA TTA CGG CGA TG - 3') e SyrB2 (5' - TTG TTG CTT GTC GAT TTT GC - 3'), que geram um produto de 202 pb. Para o desenho dos oligos específicos para detecção de E. amylovora, escolheu-se o fator de patogenicidade DspE de $198 \mathrm{kDa}$ com função homóloga ao AvrE de $P$. syringae pv. tomato (Bogdanove et al., 1998). A partir da sequência parcial associada ao fator DspE (número de acesso GenBank U94513.1) desenhou-se os oligos DspE1 (5' - CAC TGG GAA CTG AAC ACA AGG - 3') e DspE2 (5' - CAT TTC CCC GCG ATT TTT - 3') que geram um produto de 149 $\mathrm{pb}$.

\section{Especificidade dos oligonucleotídeos iniciadores}

Os oligos A1/B6, SyrB1/SyrB2 e DspE1/DspE2 foram testados separadamente quanto a especificidade pela PCR com DNA de Pss281, E. amylovora (IBSBF 551, Instituto Biológico, 2008) (Ea551), e os isolados patogênicos de Pseudomonas sp. obtidos em pomares de Vacaria (Pack9 e Pack10). As reações foram executadas em um volume final de $20 \mu \mathrm{L}$ com concentrações de reagentes e condições de reação segundo a Tabela 1 . As condições de desnaturação inicial $\left(94^{\circ} \mathrm{C}\right.$ por $\left.5 \mathrm{~min}\right)$ e extensão final $\left(72^{\circ} \mathrm{C}\right.$ durante $5 \mathrm{~min}$ ) foram iguais para todas as reações. Água Milli-Q foi utilizada como controle negativo.

TABELA 1 - Concentração final dos reagentes, condições da PCR e eletroforese utilizadas para os pares de oligonucleotídeos iniciadores usados na detecção de bactérias em gemas de pereiras europeias

\begin{tabular}{|c|c|c|c|}
\hline & A1/B6 & $\begin{array}{l}\text { SyrB1/ } \\
\text { SyrB2 }\end{array}$ & $\begin{array}{l}\text { DspE1/ } \\
\text { DspE2 }\end{array}$ \\
\hline [Oligos] & $0,5 \mu \mathrm{M}$ & $0,4 \mu \mathrm{M}$ & $0,25 \mu \mathrm{M}$ \\
\hline [Tampão de reação] & $1 \mathrm{x}$ & $1 \mathrm{x}$ & $1 \mathrm{x}$ \\
\hline [dNTP] & $0,2 \mathrm{mM}$ & $0,2 \mathrm{mM}$ & $0,2 \mathrm{mM}$ \\
\hline$\left[\mathrm{MgCl}_{2}\right]$ & $3,0 \mathrm{mM}$ & $3,5 \mathrm{mM}$ & $3,0 \mathrm{mM}$ \\
\hline [Taq DNA polimerase] & $0,25 \mathrm{U}$ & $0,25 \mathrm{U}$ & $0,25 \mathrm{U}$ \\
\hline $\begin{array}{l}\text { Programa para } \\
\text { amplificação }\end{array}$ & $\begin{array}{c}\left(94^{\circ} \mathrm{C} / 30^{\prime}, 55^{\circ} \mathrm{C} / 15^{\prime},, 72^{\circ} \mathrm{C} / 1^{\prime}\right) \\
30 \mathrm{x}\end{array}$ & $\begin{array}{c}\left(94^{\circ} \mathrm{C} / 15^{\prime \prime}, 53{ }^{\circ} \mathrm{C} / 10^{\prime \prime}, 72^{\circ} \mathrm{C} / 15^{\prime \prime}\right) \\
35 \mathrm{x}\end{array}$ & $\begin{array}{c}\left(94^{\circ} \mathrm{C} / 30^{\prime \prime}, 53^{\circ} \mathrm{C} / 40 ", 72^{\circ} \mathrm{C} / 30^{\prime \prime}\right) \\
35 \mathrm{x}\end{array}$ \\
\hline Eletroforese em gel & $\begin{array}{c}\text { Agarose } 0,8 \% \\
50 \mathrm{~V} \\
2 \mathrm{~h} 30 \mathrm{~min}\end{array}$ & $\begin{array}{c}\text { Agarose } 2 \% \\
60 \mathrm{~V} \\
2 \mathrm{~h} 30 \mathrm{~min}\end{array}$ & $\begin{array}{c}\text { Agarose } 2 \% \\
60 \mathrm{~V} \\
2 \mathrm{~h} 30 \mathrm{~min}\end{array}$ \\
\hline
\end{tabular}




\section{Sensibilidade do método}

Culturas com 24-48 h de Pss281 foram suspendidas em PBS + PVP $2 \%$ e a concentração de células padronizada por espectrofotometria para $\mathrm{DO}_{620}=0,1$. Diluições em PBS + PVP $2 \%$ foram obtidas até $10^{-10}$. Para contagem das células, $10 \mu \mathrm{L}$ de cada diluição de Pss281 foram transferidos para placas contendo meio KB. Em seguida, $500 \mu \mathrm{L}$ de cada diluição foram acrescentados a cinco gemas acondicionadas em tubos de 1,5 mL e maceradas em nitrogênio líquido com auxílio de micropistilos descartáveis. Agitaram-se os tubos em vortex por $10 \mathrm{~s}$ e deixou-se em temperatura ambiente por $10 \mathrm{~min}, 100 \mu \mathrm{L}$ foram, então, transferidos para cartões FTA. O DNA contido nos cartões FTA foi eluído após lavagem. O DNA de cada diluição de Pss281 foi utilizado na PCR com os oligos A1/B6 e SyrB1/SyrB2 a fim de se verificar o nível de detecção de $P$. syringae pv. syringe. As condições das reações seguiram as descritas na Tabela 1. DNA genômico de Pss281 foi usado como controle positivo e água Milli-Q como controle negativo.

Para testar a sensibilidade do método na detecção de E. amylovora, DNA de Ea551 em quantidade suficiente para obter concentrações de 4,68; 9,37; 18,75; 37,5; 75 e $150 \mathrm{ng} . \mu \mathrm{L}^{-1}$ foi adicionado a $500 \mu \mathrm{L}$ de PBS + PVP $2 \%$. Transferiram-se $500 \mu \mathrm{L}$ de cada diluição de DNA para tubo de $1,5 \mathrm{~mL}$ contendo cinco gemas maceradas. Agitou-se por $10 \mathrm{~s}$ e após $10 \mathrm{~min}$ transferiram-se $100 \mu \mathrm{L}$ para cartões FTA. O DNA contido nos cartões FTA foi eluído e utilizado em PCR com os oligos DspE1/DspE2. Foi utilizada água Milli-Q como controle negativo.

\section{Coleta e processamento das amostras}

A cada dois meses durante o ano de 2008, amostras foram coletadas de 50 pereiras 'Packham's Triumph' localizadas no Pomar Mussatto - Vacaria RS, totalizando
300 amostras. Cada amostra, composta por cinco gemas, foi acondicionada separadamente em tubos de $1,5 \mathrm{~mL}$. Os tubos contendo as gemas foram mergulhados em nitrogênio líquido e as gemas maceradas com micropistilos descartáveis. Adicionaram-se $500 \mu \mathrm{L}$ de PBS contendo $2 \%$ de PVP em temperatura ambiente por $10 \mathrm{~min}$. A seguir, $100 \mu \mathrm{L}$ do macerado foram transferidos para o cartão FTA e deixado secar por $24 \mathrm{~h}$. Os cartões foram armazenados dentro de sacos plásticos em temperatura ambiente. Discos de $3 \mathrm{~mm}$ do cartão FTA foram lavados, o DNA eluído e armazenado a $-20^{\circ} \mathrm{C}$.

\section{Deteç̧ão por PCR e flutuação populacional}

Dez microlitros do DNA eluído de cada amostra foram utilizados na PCR para detecção de Pseudomonas spp., P. syringae pv. syringae, E. amylovora, com os respectivos oligos A1/B6, SyrB1/SyrB2, DspE1/DspE2. As reações seguiram as condições descritas na Tabela 1 de acordo com o par de oligos utilizado. DNA genômico de Pss281 $(2 \mu \mathrm{L})$ foi utilizado como controle positivo nas reações com os oligos A1/B6 e SyrB1/SyrB2. O controle positivo nas reações com os oligos DspE1/DspE2 foi 15 ng de DNA de Ea551. Água Milli-Q foi utilizada como controle negativo. Os produtos foram visualizados através de eletroforese em gel de agarose conforme descrito na Tabela1.

\section{RESULTADOS}

\section{Padronização do método de extração de DNA e detecção por PCR}

O DNA do isolado patogênico Pack9 foi amplificado por PCR com os oligos A1/B6 independentemente do método de extração (lise alcalina, fervura, lise de Edwards

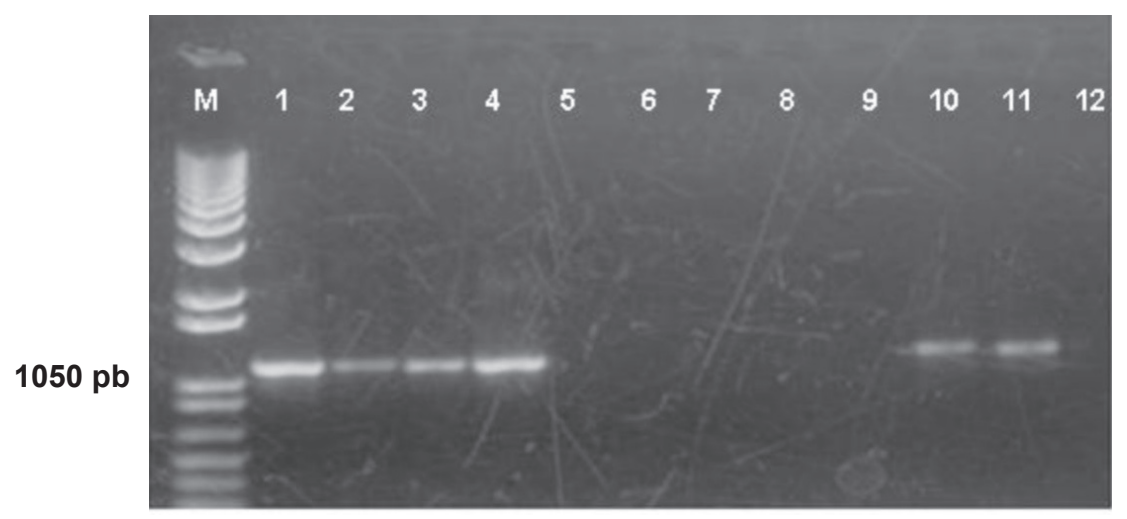

FIGURA 1 - Perfil eletroforético dos produtos de PCR com os oligonucleotídeos iniciadores A1/B6 utilizando diferentes métodos de extração de DNA do isolado patogênico Pack9, em cultura pura ou na presença de macerado de gemas de pereiras europeias: M, marcador de peso molecular $1 \mathrm{~Kb}$ Plus DNA ladder (Invitrogen); (1) Pack9/lise alcalina; (2) Pack 9/ fervura; (3) Pack9/lise de Edwards; (4) Pack9/FTA; (5) gema+Pack9/fervura; (6); gema+Pack9/lise de Edwards; (7) gema+Pack9/FTA; (8) gema+Pack9/FTA + pré-lavagem com álcool; (9) gema+Pack9/maceração com micropistilo/FTA; (10) Pack9/palito de madeira/fervura; (11) Pss281 (controle positivo); (12) água (controle negativo). (5-8) maceração com palito de madeira. 
ou FTA) (Figura 1). Entretanto, não ocorreu amplificação quando o DNA de Pack9 foi extraído (fervura, lise de Edwards, FTA e FTA com pré-lavagem em álcool $70 \%$ ) na presença de gemas de pereiras maceradas (Figura 1, canaletas 6,7 e 8). A forma de maceração (micropistilo ou palito de madeira) não interferiu na amplificação do DNA, pois ocorreu amplificação a partir do DNA extraído quando a suspensão de Pack9 foi deixada em contato com o palito de madeira, simulando-se o processo de maceração das gemas. Contudo, houve inibição da PCR quando o DNA de Pack9 foi extraído na presença de gemas maceradas com micropistilos (Figura 1, canaletas 9 e 10). Acreditava-se que por ser elaborado a partir de Pinus sp., rico em compostos tânicos, o palito de madeira pudesse inibir a PCR, entretanto os resultados encontrados mostram que a inibição da reação ocorre em decorrência da presença das gemas de pereiras e não em função do palito de madeira.

O DNA dos isolados Pack10 e Pss281 foi, assim como o DNA de Pack9, amplificado por PCR com os oligos A1/B6, independentemente do método de extração (fervura ou FTA) (Figura 2, canaletas 1-6). A amplificação do DNA de Pss281 extraído na presença de gemas de pereiras maceradas foi possível apenas quando o método de extração do DNA combinou acréscimo de PVP $2 \%$ no tampão usado para maceração das gemas e FTA com prélavagem em álcool (Figura 2, canaletas 10 e 14). A adição do tampão de lise de Edwards a este método resultou em degradação de DNA sendo, portanto, desconsiderado por representar um passo a mais sem melhorar os resultados (Figura 2, canaletas 11e 15).

\section{Especificidade dos oligonucleotídeos iniciadores}

A PCR com os oligos A1/B6 gerou produtos de 1050 pb quando o DNA de espécies de gênero Pseudomonas
(Pack9, Pack10 e Pss281) foi usado como molde. Não houve amplificação do DNA de Ea551 (Figura 3). Quando a PCR foi executada utilizando-se os oligos SyrB1/SyrB2, foi obtido apenas amplificação do DNA de Pss28, com um produto de 202 pb. O DNA dos isolados Pack9 e Pack10 não foi amplificado pela PCR com os oligos SyrB1/SyrB2. A PCR com os oligos DspE1/DspE2 gerou um produto de 149 pb a partir do DNA de Ea551 (Figura 4). Assim, confirmouse a especificidade dos oligos anteriormente verificada in silico via BLAST, sendo que para as estirpes testadas na PCR, SyrB1/SyrB2 mostrou-se específico para $P$. syringae pv. syringae e DspE1/DspE2 para E. amylovora.

\section{Sensibilidade do método}

A PCR com oligos A1/B6 e extração de DNA por FTA acrescido de PVP 2\% e pré-lavagem em álcool $70 \%$ foi

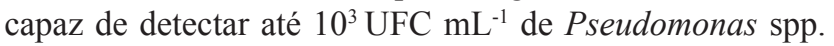
em macerado de gemas de pereiras. P. syringae pv. syringae pode igualmente ser detectada até $10^{3} \mathrm{UFC} \mathrm{mL} \mathrm{m}^{-1} \mathrm{em}$ amostra com gemas de pereiras, utilizando PCR com oligos SyrB1/ SyrB2. Para E. amylovora, o método de extração de DNA por FTA, PVP2 \% e pré-lavagem em álcool $70 \%$ seguido pela PCR com os oligos DspE1/DspE2 detectou até 9,37 ng $\mu \mathrm{L}^{-1}$ (Figura 5).

\section{Detecção e flutuação populacional}

Utilizando-se o método de extração de DNA padronizado e os oligos específicos, não houve detecção de E. amylovora em nenhuma das amostras de gemas coletadas ao longo do ano de 2008. P. syringae pv. syringae foi detectado apenas em duas de um total de 300 amostras coletadas. As amostras com detecção positiva para este patovar foram coletadas no mês de outubro. Pseudomonas spp. foram detectadas em todos os meses amostrados, na

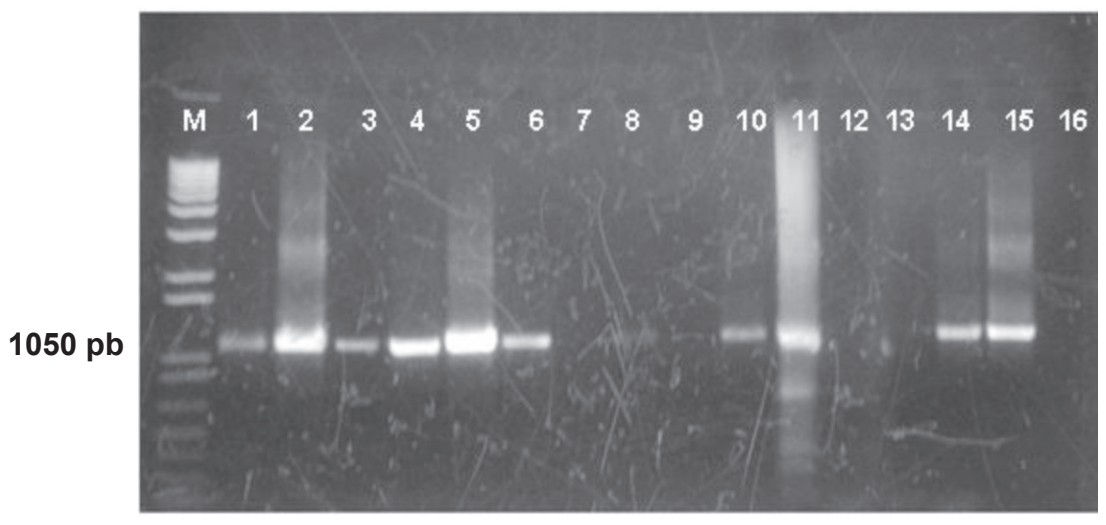

FIGURA 2 - Perfil eletroforético dos produtos de PCR com os oligonucleotídeos iniciadores A1/B6, utilizando diferentes métodos de extração de DNA, em cultura pura ou na presença de macerado de gemas de pereiras europeias: M, marcador de peso molecular $1 \mathrm{~Kb}$ Plus DNA ladder (Invitrogen); (1) Pack 9/ fervura; (2) Pack 10/ fervura; (3) Pack 9/ FTA; (4) Pack 10/ FTA; (5) Pss281/ fervura; (6) Pss281/ FTA; (7) gemas + Pss281 + PVP/fervura; (8) gemas + Pss281 + PVP/FTA; (9) gemas + Pss281 + PVP/ FTA + lise de Edwards; (10) gemas + Pss281 + PVP/ FTA + pré-lavagem com álcool; (11) gemas+Pss281 + PVP/FTA + lise de Edwards + pré-lavagem com álcool; (12-15) repetição de 8-11; (16) água (controle negativo). 


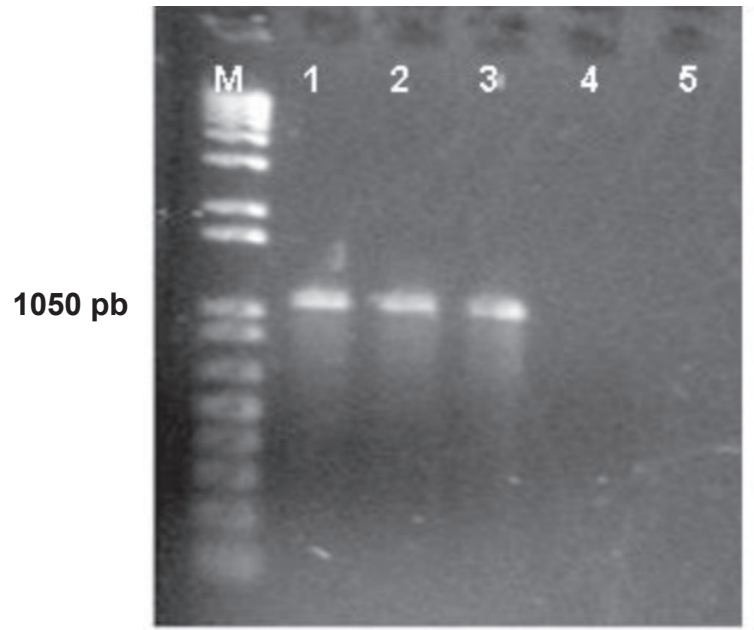

FIGURA 3 - Perfil eletroforético dos produtos de PCR com os oligonucleotídeos iniciadores A1/B6; M, marcador de peso molecular $1 \mathrm{~Kb}$ Plus DNA ladder (Invitrogen); (1) Pack 9; (2) Pack 10; (3) Pss281; (4) Ea551; (5) água (controle negativo).

$202 \mathrm{pb}$ $149 \mathrm{pb}$

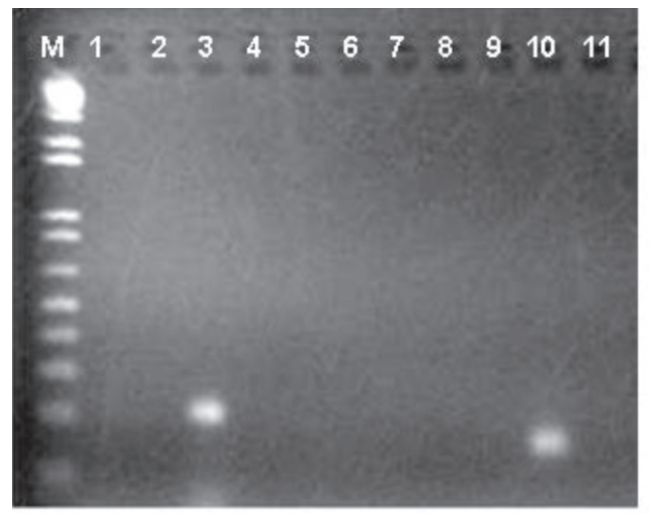

FIGURA 4 - Perfil eletroforético dos produtos de PCR com os oligonucleotídeos iniciadores SyrB1/SyrB2 (1-5), DspE1/DspE2 (7-11): M, marcador de peso molecular $1 \mathrm{~Kb}$ Plus DNA ladder (Invitrogen); (1,7) Pack 9; (2, 8) Pack 10; (3, 9) Pss281; (4, 10) Ea551; $(5,11)$ água (controle negativo).

proporção 16,3 \% do total de amostras (Figura 6). No mês de outubro obteve-se o maior número de amostras com detecção positiva para Pseudomonas spp. (30\%), seguido pelo mês de abril (22\%). Nas coletas de junho e dezembro houve a menor proporção de deteç̧ão (10\%) (Figura 6).

Pela análise das condições meteorológicas durante 2008 para região de Vacaria (estação meteorológica da Embrapa Uva e Vinho em Vacaria), verificou-se que no período que antecipou a coleta do mês de outubro houve um aumento contínuo de temperatura, com as menores amplitudes térmicas do ano. Esta mesma estabilidade na temperatura foi observada no período que antecipa a coleta
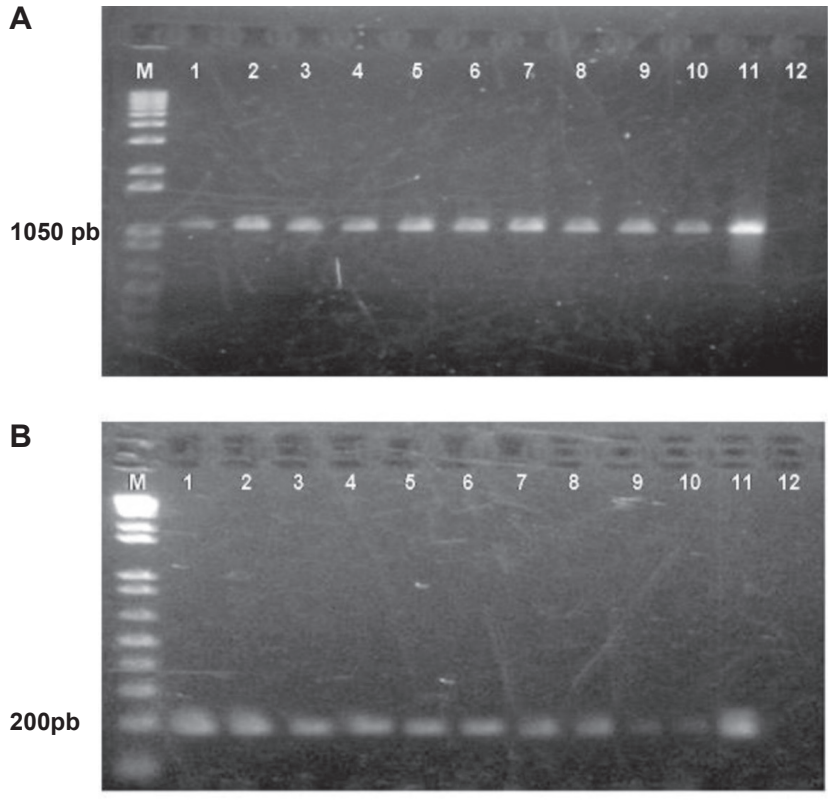

C

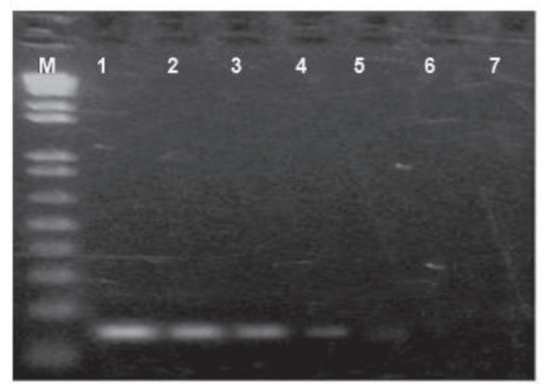

FIGURA 5 - Sensibilidade do método de detecção em gemas de pereiras europeias 'Packham's Triumph' através de extração de DNA por FTA + PVP + pré-lavagem em álcool e PCR com os oligonucleotídeos iniciadores (A) A1/B6; (B) SyrB1/SyrB2 e (C) DspE1/DspE2. (A) e (B): M, marcador de peso molecular 1 Kb Plus DNA ladder (Invitrogen); (1-10) diluições de células de Pss281 de $10^{12}$ até $10^{3}$ UFC. $\mathrm{mL}^{-1}$ em macerado de gemas; (11) controle positivo; (12) água (controle negativo). (C): M, marcador de peso molecular $1 \mathrm{~Kb}$ Plus DNA ladder (Invitrogen), diluições de DNA de Ea551 (1) 150 ng. $\mu \mathrm{L}^{-1}$; (2) 75 ng. $\mu \mathrm{L}^{-1}$; (3) 37,5 ng. $\mu \mathrm{L}^{-1}$; (4) 18,75 ng. $\mu \mathrm{L}^{-1}$; (5) 9,37 ng. $\mu \mathrm{L}^{-1}$, (6) 4,68 ng. $\mu \mathrm{L}^{-1}$ (7) água (controle negativo).

do mês de abril. No período relacionado à coleta de junho, observaram-se temperaturas baixas, com mínimas próximas a zero. Nos meses de dezembro a fevereiro registraram-se temperaturas mais altas, com máximas próximas a $30^{\circ} \mathrm{C}$. Além disso, há de se observar que no terceiro decêndio de outubro houve precipitação alta, totalizando $240 \mathrm{~mm}$.

\section{DISCUSSÃO}

A ausência de quadro sintomatológico característico da queima bacteriana, principalmente quanto à agressividade, assim como os resultados negativos da PCR são indicativos 


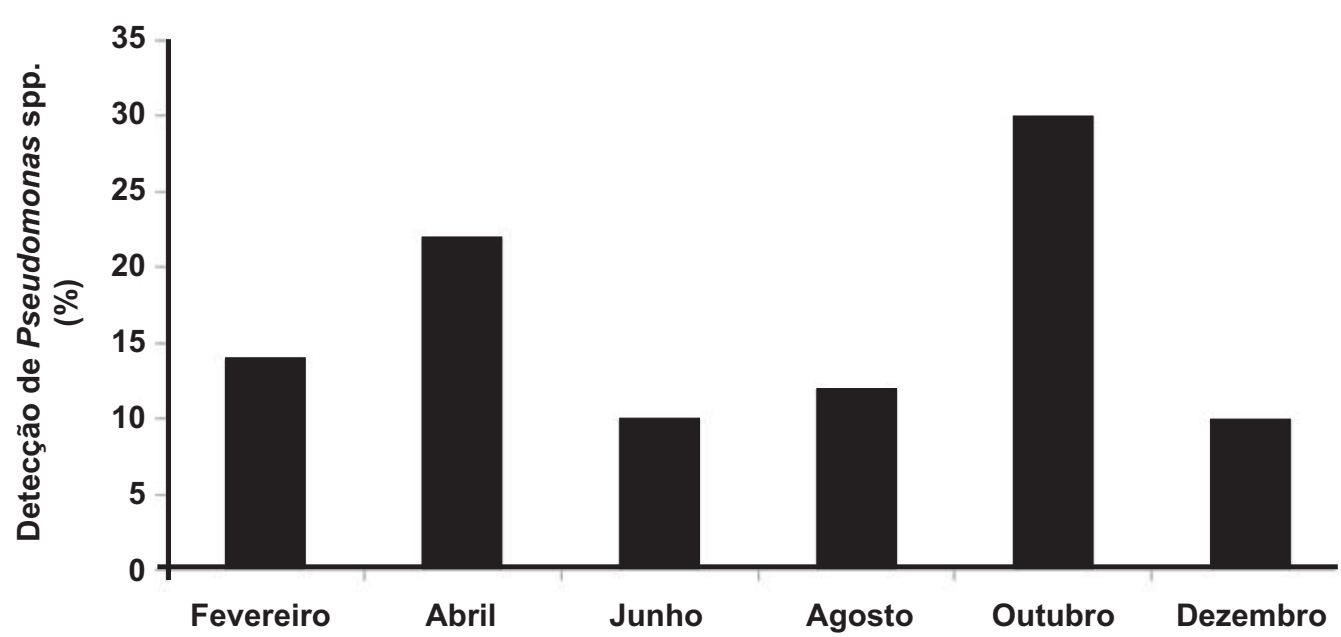

FIGURA 6 - Detecção (percentagem de amostras positivas em relação ao total de amostras analisadas) de Pseudomonas spp. em gemas de pereiras europeias através de extração de DNA por FTA + PVP + prélavagem em álcool e PCR com os oligonucleotídeos iniciadores A1/B6.

de que os sintomas observados em Vacaria não são de queima bacteriana associada a $E$. amylovora, que, no início, pode ser confundida com o crestamento bacteriano associado a P. syringae pv. syringae (Aldwinckle \& Beer, 1979; Qiu et al., 2008).

A baixa percentagem de detecção de $P$. syringae pv. syringae em gemas de pereiras 'Packham's Triumph' associado ao fato de que o DNA dos isolados patogênicos Pack9 e Pack10, entre outras características, não é amplificado pela PCR com os oligonucleotídeos específicos para $P$. syringae pv. syringae ( $\mathrm{SyrB} 1 / \mathrm{SyrB} 2)$, sugere que esta bactéria não seja o agente causal da morte de flores de pereiras europeias verificada em Vacaria RS. A baixa frequência de detecção em gemas de pereiras não permitiu que o primeiro passo dos postulados de Koch fosse cumprido para $P$. syringae pv. syringae: associação constante entre patógeno e hospedeiro. Por outro lado, Pseudomonas spp. foram detectadas em gemas de pereiras europeias 'Packham's Triumph' em todas as épocas do ano com até $30 \%$ das amostras positivas, sendo mais um indicativo, além da identificação dos isolados patogênicos obtidos, de que a morte das flores de pereiras europeias está associada a uma espécie de Pseudomonas.

Em plantas perenes, a população de Pseudomonas spp. é geralmente maior na primavera (Hirano \& Upper, 1990). Esta informação corrobora os resultados de maior percentagem de detecção de Pseudomonas spp. em gemas de pereiras no mês de outubro. Apesar de se verificar relação do período que antecipa a coleta de gemas em outubro com temperaturas mais amenas e menores oscilações, segundo Hirano \& Upper (1990) o efeito da temperatura é um fator menor e sugerem como fator determinante o aumento da atividade da planta. Sabaratnam \& Beattie (2003) afirmam que a população de Pseudomonas spp., seja ela epifítica ou endofítica, é dependente da espécie vegetal que coloniza.

A precipitação aparece como o principal fator na distribuição temporal de Pseudomonas spp., diminuindo a população em dias de chuva por lavar a superfície das plantas (Hirano \& Upper, 1990). A precipitação de $240 \mathrm{~mm}$ ocorrida no final de outubro, quatro vezes a precipitação normal para época (IPAGRO, 1989), contribuiu, assim, para o decréscimo na proporção de detecção de Pseudomonas spp. nas gemas de pereiras verificado na coleta de dezembro.

Há de se considerar que a detecção em gemas de pereiras só foi possível com o método de extração de DNA que incluiu FTA, acréscimo de PVP e pré-lavagem com álcool $70 \%$ e PCR. O uso de FTA tem aumentado a sensibilidade de detecção comparada a métodos de extração de DNA convencionais, além de propiciar a coleta de um grande número de amostras (Orlandi \& Lampel, 2000; Mbogori et al., 2006). O cartão FTA é uma matriz fibrosa, na qual os ácidos nucléicos ficam aderidos, reduzindo os passos de coleta de DNA, purificação e estocagem e, consequentemente, diminui o custo e tempo requerido para o processamento do DNA. Esta matriz fibrosa está impregnada com agentes quelantes e desnaturantes que retém e lisam os microrganismos nela aderida (Belgrader et al., 1995). O PVP, por sua vez, tem a propriedade de formar pontes de hidrogênio com fenóis (Young et al.,1993), que são substâncias constituintes da lignina, portanto, presentes em abundância nas gemas de pereiras e inibidoras da PCR. O método permitiu alcançar níveis de detecção de P. syringae pv. syringae comparáveis aos encontrados por Kerkoud et al. (2002) com detecção de $6 \times 10^{2} \mathrm{UFC} \mathrm{mL}^{-1}$ de Pseudomonas syringae pv. papulans em macieira.

Os resultados indicaram que E. amylovora não está associada à doença observada em Vacaria RS, o que é importante para o manejo da morte de flores de pereiras 
europeias, pois descarta a possibilidade de associação com uma praga quarentenária. Embora ainda não tenha sido possível elucidar a espécie do agente causal associado à morte de flores de pereiras europeias, foi demonstrada a associação com o gênero Pseudomonas, o que fornece subsídios para o desenvolvimento de métodos de controle

\section{REFERÊNCIAS BIBLIOGRÁFICAS}

Aldwinckle HS, Beer SV (1979) Fire blight and its control. Horticulture Review 1:423-474.

Belgrader P, Del Rio SA, Turner KA, Marino MA, Weaver KR, Williams PPE (1995) Automated DNA purification and amplification from blood-stained cards using a robotic workstation. Biotechniques 19:426-432.

Bogdanove AL, Bauer BW, Beer SV (1998) Erwinia amylovora secretes DspE, a pathogenicity factor and functional AvrE homolog, through the Hrp (Type III Secretion) pathway. Journal of Bacteriology 180:2244-2247.

Camelatto D, Arruda JJP, Nachtigall GR (1997) Abortamento de gemas florais da pereira (Pyrus communis L.) cvs. Packham's Triumph e William's Bon Chretien. Resumos, VI. Congresso Brasileiro de Fisiologia Vegetal. Belém PA. p. 485.

Edwards K, Johnstone C, Thompson C (1991) A simple and rapid method for preparation of plant genomic DNA for the PCR analysis. Nucleic Acids Research 19:1349.

FAO. Peras y membrillos. http:/faostat.fao.org/site/339/default. aspx Acesso 07 de agosto de 2007.

Genbank. Plataforma BLAST. http://www.ncbi.nlm.nih.gov/ BLAST/Blast.cgi?CMD=Web\&PAGE_TYPE=BlastHome Acesso 15 de setembro de 2008.

Hirano SS, Upper D (1990) Population biology and epidemiology of Pseudomonas syringae. Annual Review of Phytopathology 28:155-170.

Instituto Biológico. Coleção de fitobactérias. http://www.biologico. sp.gov.br/bacterias.php

IPAGRO - Instituto de Pesquisas Agronômicas (1989) Seção de Ecologia Agrícola. Atlas Agroclimático do Estado do Rio Grande do Sul. Vol. 3. Porto Alegre RS.

Kerkoud M, Manceau C, Paulin JP (2002) Rapid diagnosis of Pseudomonas syringae pv. papulans, the causal agent of blister spot of apple, by polymerase chain reaction using specifically designed $h r p L$ gene primers. Phytopathology 92:1077-1083.

Manceau C, Horvais A (1997) Assesment of genetic diversity among strains of Pseudomonas syringae by PCR-restriction fragment length polymorphism analysis of rRNA operons with special emphasis on Pseudomonas syringae pv. tomato. Applied and Environmental Microbiology 63:498-505.

Mansvelt EL, Hatting MJ (1990) Bacterial blossom blast. In: Jones AL, Aldwinckle HS (Eds.) Compendium of Apple and Pear Diseases. The American Phytopathological Society, St. Paul, MN, pp. 64.
Mbogori MN, Kimani M, Kuria A, Lagat M, Danson JW (2006) Optimization of technology for large scale plant DNA isolation for use in marker assisted selection. African Journal of Biotechnology 9:693-696.

Miller TD, Schroth MN (1972) Monitoring the epiphytic population of Erwinia amylovora on pear with a selective medium. Phytopathology 62:1175-1182.

Ministério da Agricultura. Lista de pragas quarentenárias. http:// www.agricultura.gov.br Acesso 15 de agosto de 2008.

Montesinos E, Vilardell P (2001) Effect of bactericides, phosphonates and nutrient amendments on blast of dormant flower buds of pear: a field evaluation for disease control. European Journal of Plant Pathology 109:787-794.

Nakasu BH, Leite DL (1990) Indicação de porta-enxerto e cultivares de pereira para o Sul do Brasil. HortiSul 1:20-24.

Nakasu BH, Leite DL (1992) Pirus 9 - Seleção de pereira para o Sul do Brasil. HortiSul 2:19-20.

NCBI. National Center for Biotechnology Information. http:// www.ncbi.nlm.nih.gov/entrez/ Acesso 15 de setembro de 2008

Orlandi PA, Lampel KA (2000) Extraction-free, filter-based template preparation for rapid and sensitive PCR detection of pathogenic parasitic protozoa. Journal of Clinical Microbiology 38:2271-2277.

Panagopoulos CG, Crosse L (1964) Blossom Blight and related symptoms caused by Pseudomonas syringae Van Hall on pear trees. Kent. Annual Report of the East Malling Research Station. pp. $119-122$.

Primer 3: Desenho de oligonucleotídeos iniciadores a partir de sequências de DNA. http://biotools.umassmed.edu/bioapps/ primer3_www.cg

Qiu W, Huai Y, Xu F, Xu L, Xie G, Li B, Yu S, Liu J (2008) Pear blossom blast caused by Pseudomonas syringae pv syringae in China. Agricultural Sciences in China 7:1091-1096.

Rajendram D, Ayenza R, Holder FM, Moran B, Long T, Shah HN (2006) Long-term storage and safe retrieval of DNA from microorganisms for molecular analysis using FTA matrix cards. Journal of Microbiological Methods 67:582-592.

Rommel CC (2009) Etiologia e epidemiologia da morte de flores de pereiras europeias (Pyrus communis L.) no Rio Grande do Sul. Dissertação de Mestrado. Universidade Federal do Rio Grande do Sul. Porto Alegre RS.

Sabaratnam S, Beattie GA (2003) Differences between Pseudomonas syringae pv. syringae $\mathrm{B} 728 \mathrm{a}$ and Pantoea agglomerans BRT98 in epiphytic and endophytic colonization of leaves. Applied and Environmental Microbiology 69:1220-1228.

Schaad NW, Jones JB, Chun W (2001) Laboratory guide for identification of plant pathogenic bacteria. 3 ed. Saint Paul MN. APS Press.

Young CC, Burghoff RL, Keim LG, Minak-Bernero V, Lute JR, Hinton SM (1993) Polyvinylpyrrolidone-agarose gel electrophoresis purification of polymerase chain reactionamplifiable DNA from soils. Applied and Environmental Microbiology 59:1972-1974. 